\title{
Application Research on the Construction of International Talent Quality Evaluation System based on Industrial Multi-Objective Allocation AHP Hierarchical Analysis Method
}

\author{
Cong Qiao, Huayan Xing, Haojie Zhao, Xin Wang, Ming Xue \\ Zhengzhou Railway Vocational Technical College, Zhengzhou, Henan, 451460, China
}

\begin{abstract}
At present, the state vigorously promotes open education, encourages higher vocational institutions to attract foreign high-quality educational resources, improves the level of international education, and cultivates high-quality, highly skilled talents with international vision, knowledge of international rules, and international competitiveness, while meeting the needs of actual social and economic development. How to cultivate internationalized technical and skilled talents and improve the quality of talent cultivation has become a new issue facing the development of vocational education in China. This article adopts the AHP hierarchical analysis method, which is widely used in industrial power distribution, regional economic planning, livestock development strategy, industrial sector setting and can realize the study of multi-level target problems, constructs an evaluation system consisting of 4 primary indicators and 15 secondary indicators, evaluates the quantitative and qualitative analysis of talent training quality, gives suggestions to improve the quality of internationalized talent training, and provides suggestions for higher vocational.
\end{abstract}

Keywords: internationalized talents; cultivation quality; hierarchical analysis; evaluation system; indicators;industrial distribution; multi-level target.

\section{Introduction}

The National Medium and Long-term Education Reform and Development Plan (2010-2020) clearly points out that the new period of expanding education opening up to the outside world should improve the internationalization of China's education and enhance the international status, influence and competitiveness of China's education. Vocational colleges and universities should take the initiative to participate in the national "One Belt and One Road" construction, actively learn from foreign advanced experience, improve the level of international education, and realize the internationalization for Chinese enterprises going abroad and enterprises along the "Belt and Road". The university will provide international talents for Chinese enterprises going abroad and enterprises in the countries along the "One Belt and One Road". By the end of 2020, according to the data of the information platform of the Ministry of Education on the supervision of Sino-foreign cooperative schooling, more than 400 of China's 1,418 colleges and universities have cooperated with foreign institutions in schooling, establishing 39 joint institutions, more than 900 projects and nearly 50,000 students. So in the face of such a large number of students, how to evaluate whether they have international comprehensive quality and what kind of traits can be called international professional talents has become an urgent problem for higher vocational education. It is imperative to build a scientific and reasonable evaluation index system, which is the urgent problem to be solved and can be used as a scientific reference basis for the adjustment of teaching objectives, construction of course contents, reform of teaching methods and selection of talents from enterprises.

\section{Analysis of the Current State of Student Quality Assessment}

In China, traditional methods are mostly used for talent quality research, mainly in the form of course examinations, and the subjective concept is still adhering to the score first, following the traditional method of evaluating students. Most of the higher education institutions in China adopt the way of calculating the subject

ISSN: 0010-8189

(C) CONVERTER 2020

www.converter-magazine.info 
examination results to evaluate the cultivation difference of the students, often neglecting the examination of students' quality, moral and ideological aspects. As a result, "course examination score" becomes the only or dominant score in the comprehensive evaluation of higher vocational students, which is obviously not consistent with the essence of vocational education to cultivate students' vocational development. The quality of students should be evaluated in terms of academic performance, learning ability, creative thinking, social adaptability, interpersonal skills, organizational and collaborative skills, self-control and other aspects, and not only defined by the high or low scores of subject examinations. In addition, international technical skill talents should be proficient in foreign language communication, professional application skills, international cognition, thinking and vision, and be familiar with the technical standards of their field. It can be seen that the factors determining the quality of talent training are a combination of dynamic and static, and the factors are full of correlations, not all of which can be quantitatively measured in the same way as test scores. Therefore, it is objectively necessary to combine quantitative and qualitative evaluation of student training quality, so as to improve the scientificity of evaluation methods and the validity of evaluation results. Therefore, it is necessary to build a modern comprehensive quality evaluation system, analyze the influencing factors of talent cultivation quality, clearly judge the focus of talent cultivation, and conduct quantitative and qualitative evaluation [1].

In recent years, the traditional backward theoretical knowledge-based assessment and the evaluation methods are gradually eliminated, and more models are gradually applied to the evaluation of the student training quality in order to build the scientific and effective comprehensive evaluation system. Commonly used methods are mainly DEA, PCA, TOPSIS, AHP and others, and different models have their own advantages and disadvantages [2]. DEA data envelopment analysis method is conducive to the evaluation from the perspective of decision indicators, but reflects the relative nature of the evaluated factors compared to a particular factor, emphasizes the two-by-two evaluation relative to a certain indicator, cannot realize the ranking of all evaluation indicators. The PCA principal-form analysis method itself has a more centralized data collection, which can be to analyze as a whole and reduce the algorithmic workload. At the same time, the matrix feature decomposition of this method is more limited, and the results may not be optimal. TOPSIS superior-inferior solution distance method is a common method in multi-objective decision analysis, which can make full use of the original data information and reflect the gap between each index [5]. The AHP hierarchical analysis method can make full use of the opinions of the evaluation subjects and conduct an overall comprehensive evaluation of the hierarchical structure, which can realize layer-by-layer analysis and decomposition, and achieve the purpose of transforming into a single-criteria evaluation from the comprehensive level on the basis of multiple complex factor structures. The method effectively combines qualitative analysis with quantitative analysis, converts semi-qualitative and semi-quantitative problems into quantitative calculation problems, can rank the importance of influencing factors, realizes the establishment of a hierarchy of non-quantitative and quantitative factors, and clearly presents the relationship between each layer, each criterion and each element. At the same time, the method has a simple evaluation procedure and an easy-to-understand calculation process, and it is still possible to calculate the importance of each element even when there are omissions or deficiencies in the research data. Therefore, it seems to be more appropriate to use the AHP hierarchical analysis method to make the comprehensive assessment of the quality of international technical skills personnel [3].

\section{Research Method Construction}

\subsection{Evaluation data selection}

The trend of economic globalization is unstoppable, and it is the major trend for Chinese enterprises to "go global", and the tide will be surging. According to the survey, $93 \%$ of Chinese enterprises do not have enough qualified international talents in the process of "going global". In the past 20 years since the slogan "Chinese enterprises go global" was proposed in 2003, the lack of international talents has been the main constraint for Chinese enterprises to make overseas investment, expand the scale of international operation and improve the level of internationalization. Therefore, enterprises which want to survive and develop in foreign countries need a high 
level of international talents to inject the driving force. According to the survey data, for Chinese enterprises doing business overseas or planning to "go global", qualified international talents should be proficient in multiple languages, have overseas study and work experience, possess global vision and innovative thinking, cross-cultural communication and coordination ability, be familiar with international rules, have active learning ability and flexible adaptability, have International analytical skills, understanding of transnational business operations, and the ability to work in foreign countries which are the composite talents of management and professional and technical skills. Therefore, this paper selects the talent training program of the Sino-Russian joint railway vehicle program of a college for the class of 2020 as the source of research data, sets the training objectives and specifications of the program, the curriculum setting system inside and outside the classroom, the teaching task arrangement, evaluation and quality management, graduation requirements, knowledge and skills mastery norms, literacy and ability requirements as the evaluation indexes, and constructs, calculates and judges the indexes in the hierarchical system [4].

\subsection{Indicator system construction}

\section{a) Metrics grading scale construction}

According to the AHP hierarchical analysis method, through the study of international talent cultivation quality evaluation indexes, considering the various indicators affecting the decision and their interrelationship, and combining the characteristics of talent cultivation, we summarize the evaluation indexes in 4 categories and 15 subcategories and draw the hierarchical structure diagram, as shown in Table $1[6,7]$.

Table 1.Evaluation index system

\begin{tabular}{|c|c|c|c|c|}
\hline $\begin{array}{l}\text { Olevel } \\
\text { indicators }\end{array}$ & $\begin{array}{l}\text { Clevel } \\
\text { indicators }\end{array}$ & Plevel 3 indicators & $\begin{array}{l}\text { Content of the level } 3 \\
\text { indicators }\end{array}$ & $\begin{array}{l}\text { Quantification method } \\
\text { of level } 3 \text { indicators }\end{array}$ \\
\hline 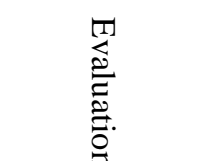 & \multirow{3}{*}{$\begin{array}{l}\text { C1 Multilingual } \\
\text { Language } \\
\text { Skills }\end{array}$} & $\begin{array}{l}\text { P1 Russian } \\
\text { language skills }\end{array}$ & $\begin{array}{l}\text { Ability to use Russian as a } \\
\text { working language fluently }\end{array}$ & $\begin{array}{l}\text { Based on the formative } \\
\text { assessment results of } \\
\text { the Russian course }\end{array}$ \\
\hline 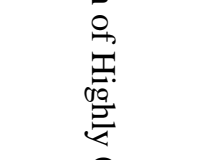 & & $\begin{array}{l}\text { P2 English } \\
\text { language skills }\end{array}$ & $\begin{array}{l}\text { Ability to use English as a } \\
\text { working language fluently }\end{array}$ & $\begin{array}{l}\text { Based on the formative } \\
\text { assessment results of } \\
\text { the English course }\end{array}$ \\
\hline 胥 & & $\begin{array}{l}\text { P3 Other foreign } \\
\text { language skills }\end{array}$ & $\begin{array}{l}\text { Ability to master other minor } \\
\text { languages }\end{array}$ & $\begin{array}{l}\text { Based on individual } \\
\text { mastery of other foreign } \\
\text { languages }\end{array}$ \\
\hline 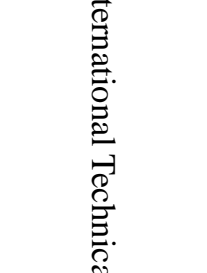 & \multirow{3}{*}{$\begin{array}{l}\mathrm{C} 2 \\
\text { Communication } \\
\text { and } \\
\text { coordination } \\
\text { skills }\end{array}$} & $\begin{array}{l}\mathrm{P} 4 \quad \text { Interpersonal } \\
\text { communication } \\
\text { skills }\end{array}$ & $\begin{array}{l}\text { Ability to think } \\
\text { internationally and handle } \\
\text { relationships inside and } \\
\text { outside the organization } \\
\text { properly }\end{array}$ & $\begin{array}{l}\text { Based on students' } \\
\text { scores on the career } \\
\text { core competency } \\
\text { assessment }\end{array}$ \\
\hline 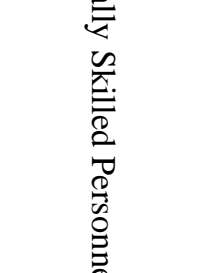 & & $\begin{array}{l}\text { P5 Cultural } \\
\text { knowledge base }\end{array}$ & $\begin{array}{l}\text { Knowledge of the cultural } \\
\text { characteristics of other } \\
\text { countries, with the } \\
\text { appropriate intellectual } \\
\text { background }\end{array}$ & $\begin{array}{l}\text { Based on the } \\
\text { performance of elective } \\
\text { courses and related } \\
\text { activities }\end{array}$ \\
\hline$\frac{1}{0}$ & & $\begin{array}{ll}\text { P6 } & \text { Teamwork } \\
\text { ability } & \end{array}$ & $\begin{array}{l}\text { Ability to participate in } \\
\text { teamwork and solve problems }\end{array}$ & $\begin{array}{l}\text { Based on students' } \\
\text { scores on the career }\end{array}$ \\
\hline
\end{tabular}


Volume 2021, No. 4

\begin{tabular}{|c|c|c|c|}
\hline & & together & $\begin{array}{l}\text { core competency } \\
\text { assessment }\end{array}$ \\
\hline & $\begin{array}{l}\text { P7 Organizational } \\
\text { leadership }\end{array}$ & $\begin{array}{l}\text { Ability to organize work } \\
\text { schedules and lead teams to } \\
\text { achieve goals }\end{array}$ & $\begin{array}{l}\text { Based on students' } \\
\text { scores on the career } \\
\text { core competency } \\
\text { assessment }\end{array}$ \\
\hline \multirow{4}{*}{$\begin{array}{l}\text { C3 Professional } \\
\text { skills }\end{array}$} & $\begin{array}{l}\text { P8 Professional } \\
\text { learning ability }\end{array}$ & $\begin{array}{l}\text { The ability to learn that is } \\
\text { necessary for a competent } \\
\text { career }\end{array}$ & $\begin{array}{l}\text { Based on the overall } \\
\text { situation of skill } \\
\text { competition and } \\
\text { practical training }\end{array}$ \\
\hline & $\begin{array}{l}\text { P9 Skill acquisition } \\
\text { ability }\end{array}$ & $\begin{array}{l}\text { Possess the technical skills } \\
\text { necessary for a competent } \\
\text { career }\end{array}$ & $\begin{array}{l}\text { Based on the overall } \\
\text { situation of skill } \\
\text { competition } \\
\text { practical training }\end{array}$ \\
\hline & P10 Moral quality & $\begin{array}{l}\text { Have the right moral } \\
\text { understanding and behavior } \\
\text { level, love and dedication to } \\
\text { work, honesty and } \\
\text { trustworthiness }\end{array}$ & $\begin{array}{l}\text { Based on the formative } \\
\text { assessment scores of } \\
\text { courses related to } \\
\text { ideological and political } \\
\text { education }\end{array}$ \\
\hline & $\begin{array}{l}\text { P11 Social } \\
\text { responsibility }\end{array}$ & $\begin{array}{l}\text { Fulfill their professional } \\
\text { obligations to society and } \\
\text { others, and consciously strive } \\
\text { to make contributions to } \\
\text { society and others }\end{array}$ & $\begin{array}{l}\text { Points based } \text { on } \\
\text { participation in social } \\
\text { activities }\end{array}$ \\
\hline \multirow{4}{*}{$\begin{array}{l}\text { C4 Diversified } \\
\text { vision }\end{array}$} & $\begin{array}{l}\text { P12 International } \\
\text { cognition, thinking, } \\
\text { vision }\end{array}$ & $\begin{array}{l}\text { Clear knowledge and clear } \\
\text { thinking about the frontiers of } \\
\text { international development }\end{array}$ & $\begin{array}{l}\text { Evaluation based on the } \\
\text { results of } \\
\text { internationalization } \\
\text { knowledge contest and } \\
\text { related activities }\end{array}$ \\
\hline & $\begin{array}{l}\text { P13 Good } \\
\text { knowledge of } \\
\text { international } \\
\text { technical standards }\end{array}$ & $\begin{array}{l}\text { Awareness of international } \\
\text { standards and regulatory } \\
\text { requirements in their field of } \\
\text { expertise }\end{array}$ & $\begin{array}{l}\text { Evaluation based on the } \\
\text { results of } \\
\text { internationalization } \\
\text { knowledge contest and } \\
\text { related activities }\end{array}$ \\
\hline & $\begin{array}{l}\text { P14 International } \\
\text { knowledge } \\
\text { structure }\end{array}$ & $\begin{array}{l}\text { Deep expertise and broad } \\
\text { knowledge }\end{array}$ & $\begin{array}{l}\text { Evaluation based on the } \\
\text { results of } \\
\text { internationalization } \\
\text { knowledge contest and } \\
\text { related activities }\end{array}$ \\
\hline & $\begin{array}{l}\mathrm{P} 15 \quad \text { International } \\
\text { innovative } \\
\text { competitive } \\
\text { awareness }\end{array}$ & $\begin{array}{l}\text { With a sense of competition, a } \\
\text { strong will and the courage to } \\
\text { think and do, a hundred brave } \\
\text { and innovative spirit }\end{array}$ & $\begin{array}{l}\text { Evaluation based on the } \\
\text { results of } \\
\text { internationalization } \\
\text { knowledge contest and }\end{array}$ \\
\hline
\end{tabular}




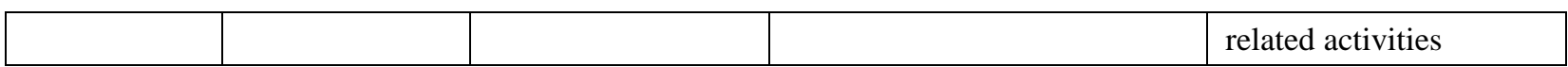

b) Build judgment matrix and consistency test

The authors invited several experts who have been engaged in front-line international education cooperation and joint education for many years, and obtained the experts' judgment scores of each evaluation index by questionnaire, determined the scale values among the indexes in each layer, determined the judgment matrix and conducted consistency tests on them. The judgment matrix between the indicators of the criterion layer for the target layer is shown in Table 2, and the judgment matrix between the indicators of the program layer for the criterion layer is shown in Tables 3 6.

Table 2 Judgment matrix O-C

\begin{tabular}{|c|c|c|c|c|c|c|c|}
\hline $\mathrm{O}$ & $\begin{array}{l}\text { C1 Multilingual } \\
\text { Language Skills }\end{array}$ & $\begin{array}{c}\text { C2 Communication } \\
\text { and coordination } \\
\text { skills }\end{array}$ & $\begin{array}{c}\text { C3 } \\
\text { Profession } \\
\text { al skills }\end{array}$ & $\begin{array}{c}\text { C4 } \\
\text { Diversifie } \\
\text { d vision }\end{array}$ & $\begin{array}{c}\text { Arith } \\
\text { meti } \\
\mathrm{c} \\
\text { avera } \\
\text { ge } \\
\text { weig } \\
\text { ht }\end{array}$ & $\begin{array}{c}\text { Geo } \\
\text { metri } \\
\text { c } \\
\text { aver } \\
\text { age } \\
\text { weig } \\
\text { hts }\end{array}$ & $\begin{array}{c}\text { Eige } \\
\text { nvalu } \\
\mathrm{e} \\
\text { meth } \\
\text { od } \\
\text { weig } \\
\text { hts }\end{array}$ \\
\hline $\begin{array}{c}\text { Multilingual } \\
\text { Language Skills }\end{array}$ & 1 & 3 & 5 & 7 & $\begin{array}{c}0.57 \\
91\end{array}$ & $\begin{array}{c}0.58 \\
06\end{array}$ & $\begin{array}{c}0.581 \\
7\end{array}$ \\
\hline $\begin{array}{l}\text { Communication } \\
\text { and coordination } \\
\text { skills }\end{array}$ & $1 / 3$ & 1 & 2 & 4 & $\begin{array}{c}0.23 \\
26\end{array}$ & $\begin{array}{c}0.23 \\
18\end{array}$ & $\begin{array}{c}0.231 \\
4\end{array}$ \\
\hline Professional skills & $1 / 5$ & $1 / 2$ & 1 & 2 & $\begin{array}{c}0.12 \\
13 \\
\end{array}$ & $\begin{array}{c}0.12 \\
13\end{array}$ & $\begin{array}{c}0.120 \\
5\end{array}$ \\
\hline Diversified vision & $1 / 7$ & $1 / 4$ & $1 / 2$ & 1 & $\begin{array}{c}0.06 \\
70\end{array}$ & $\begin{array}{c}0.06 \\
63\end{array}$ & $\begin{array}{c}0.066 \\
4\end{array}$ \\
\hline
\end{tabular}

Table 3 Judgment matrix C1-P

\begin{tabular}{|c|c|c|c|c|c|c|}
\hline $\mathrm{C} 1$ & $\begin{array}{c}\text { Russian } \\
\text { language } \\
\text { skills }\end{array}$ & $\begin{array}{c}\text { English } \\
\text { language } \\
\text { skills } \\
\text { foreign } \\
\text { language } \\
\text { skills }\end{array}$ & $\begin{array}{c}\text { Other } \\
\text { average } \\
\text { weight }\end{array}$ & $\begin{array}{c}\text { Arithmetic } \\
\text { average } \\
\text { weights }\end{array}$ & $\begin{array}{c}\text { Eigenvalue } \\
\text { method } \\
\text { weights }\end{array}$ \\
\hline $\begin{array}{c}\text { Russian language } \\
\text { skills }\end{array}$ & 1 & 1 & 3 & 0.4286 & 0.4286 & 0.4286 \\
\hline $\begin{array}{c}\text { English language } \\
\text { skills }\end{array}$ & 1 & 1 & 3 & 0.4286 & 0.4286 & 0.4286 \\
\hline $\begin{array}{c}\text { Other foreign } \\
\text { language skills }\end{array}$ & $1 / 3$ & $1 / 3$ & 1 & 0.1429 & 0.1429 & 0.1429 \\
\hline
\end{tabular}

The maximum eigenvalue is: $3.0000 ; \mathrm{CR}=-2.1350 \mathrm{e}-15<0.10$ (Passed the consistency test) 
Table 4 Judgment matrix C2-P

\begin{tabular}{|c|c|c|c|c|c|c|c|}
\hline C2 & $\begin{array}{c}\text { Interpersonal } \\
\text { communicatio } \\
\text { n skills }\end{array}$ & $\begin{array}{c}\text { Cultural } \\
\text { knowledg } \\
\text { e base }\end{array}$ & $\begin{array}{c}\text { Teamwor } \\
\mathrm{k} \text { ability }\end{array}$ & $\begin{array}{c}\text { Organizationa } \\
\text { l leadership }\end{array}$ & $\begin{array}{c}\text { Arithmeti } \\
\mathrm{c} \text { average } \\
\text { weight }\end{array}$ & $\begin{array}{c}\text { Geometri } \\
\mathrm{c} \text { average } \\
\text { weights }\end{array}$ & $\begin{array}{c}\text { Eigenvalu } \\
\text { e method } \\
\text { weights }\end{array}$ \\
\hline $\begin{array}{c}\text { Interpersonal } \\
\text { communicatio } \\
\text { n skills }\end{array}$ & 1 & 1 & 1 & 2 & 0.2770 & 0.2761 & 0.2769 \\
\hline $\begin{array}{c}\text { Cultural } \\
\text { knowledge } \\
\text { base }\end{array}$ & 1 & 1 & 1 & 3 & 0.3048 & 0.3056 & 0.3050 \\
\hline $\begin{array}{c}\text { Teamwork } \\
\text { ability }\end{array}$ & 1 & 1 & 1 & 3 & 0.3048 & 0.3056 & 0.3050 \\
\hline $\begin{array}{c}\text { Organizational } \\
\text { leadership }\end{array}$ & $1 / 2$ & $1 / 3$ & $1 / 3$ & 1 & 0.1135 & 0.1127 & 0.1131 \\
\hline \multicolumn{2}{c}{ The maximum eigenvalue is: $4.0206 ; \mathrm{CR}=0.0077<0.10$ (Passed the consistency test) } \\
\hline
\end{tabular}

Table 5 Judgment matrix C3-P

\begin{tabular}{|c|c|c|c|c|c|c|c|}
\hline C3 & $\begin{array}{c}\text { Professional } \\
\text { learning } \\
\text { ability }\end{array}$ & $\begin{array}{c}\text { Skill } \\
\text { acquisition } \\
\text { ability }\end{array}$ & $\begin{array}{c}\text { Moral } \\
\text { quality }\end{array}$ & $\begin{array}{c}\text { Social } \\
\text { responsibility }\end{array}$ & $\begin{array}{c}\text { Arithmetic } \\
\text { average } \\
\text { weight }\end{array}$ & $\begin{array}{c}\text { Geometric } \\
\text { average } \\
\text { weights }\end{array}$ & $\begin{array}{c}\text { Eigenvalue } \\
\text { method } \\
\text { weights }\end{array}$ \\
\hline $\begin{array}{c}\text { Professional } \\
\text { learning ability }\end{array}$ & 1 & 1 & 4 & 4 & 0.3860 & 0.3860 & 0.3861 \\
\hline $\begin{array}{c}\text { Skill acquisition } \\
\text { ability }\end{array}$ & 1 & 1 & 5 & 5 & 0.4314 & 0.4315 & 0.4316 \\
\hline $\begin{array}{c}\text { Moral quality } \\
\text { Social }\end{array}$ & $1 / 4$ & $1 / 5$ & 1 & 1 & 0.0913 & 0.0913 & 0.0911 \\
\hline responsibility & $1 / 4$ & $1 / 5$ & 1 & 1 & 0.0913 & 0.0913 & 0.0911 \\
\hline
\end{tabular}

The maximum eigenvalue is: $4.0062 ; \mathrm{CR}=0.0023<0.10$ (Passed the consistency test)

Table 6 Judgment matrix C4-P

\begin{tabular}{|c|c|c|c|c|c|c|c|}
\hline $\mathrm{C} 4$ & $\begin{array}{l}\text { International } \\
\text { cognition, } \\
\text { thinking, } \\
\text { vision }\end{array}$ & $\begin{array}{c}\text { Good } \\
\text { knowledge } \\
\text { of } \\
\text { international } \\
\text { technical } \\
\text { standards }\end{array}$ & $\begin{array}{c}\text { International } \\
\text { knowledge } \\
\text { structure }\end{array}$ & $\begin{array}{c}\text { International } \\
\text { innovative } \\
\text { competitive } \\
\text { awareness }\end{array}$ & $\begin{array}{c}\text { Arithmetic } \\
\text { average } \\
\text { weight }\end{array}$ & $\begin{array}{c}\text { Geometric } \\
\text { average } \\
\text { weights }\end{array}$ & $\begin{array}{c}\text { Eigenvalue } \\
\text { method } \\
\text { weights }\end{array}$ \\
\hline $\begin{array}{l}\text { International } \\
\text { cognition, } \\
\text { thinking, } \\
\text { vision }\end{array}$ & 1 & 1 & 1 & 2 & 0.2964 & 0.2951 & 0.2979 \\
\hline Good & 1 & 1 & 1 & 1 & 0.2464 & 0.2481 & 0.2463 \\
\hline
\end{tabular}

ISSN: 0010-8189 


\begin{tabular}{|c|c|c|c|c|c|c|c|}
\hline $\begin{array}{l}\text { knowledge } \\
\text { of } \\
\text { international } \\
\text { technical } \\
\text { standards }\end{array}$ & & & & & & & \\
\hline $\begin{array}{c}\text { International } \\
\text { knowledge } \\
\text { structure }\end{array}$ & 1 & 1 & 1 & 1 & 0.2464 & 0.2481 & 0.2463 \\
\hline $\begin{array}{l}\text { International } \\
\text { innovative } \\
\text { competitive } \\
\text { awareness }\end{array}$ & $1 / 2$ & 1 & 1 & 1 & 0.2107 & 0.2087 & 0.2096 \\
\hline
\end{tabular}

c) Calculate the weight of each indicator and the combined weight

On the basis of the judgment matrix, the consistency test is conducted on the judgment matrix first, and the consistency ratio $\mathrm{CR}$ is less than 0.1 after calculation, which means that the consistency test of the judgment matrix is passed [8].

The weights among the indicators in the criterion layer for the target layer $(\mathrm{O}-\mathrm{C})$ and the solution layer for the criterion layer (C-P) are obtained by using the arithmetic average method, the geometric average method and the eigenvalue method to find the weights. From the calculation results, it can be seen that the indicator weights obtained by the three methods are basically the same. The weights of the eigenvalue method are selected, and then the weights of the combination of the program layer to the target layer are calculated. 15 tertiary indicators have the following influence weights on the evaluation of high-quality international technically skilled personnel: Russian language ability (24.93\%), English language ability (24.93\%), other foreign language ability (8.31\%), cultural knowledge reserve $(7.06 \%)$, teamwork ability $(7.06 \%)$, and interpersonal skills $(6.41 \%)$, skills mastery $(5.20 \%)$, professional learning ability $(4.65 \%)$, organizational leadership $(2.62 \%)$, international cognition, thinking, vision $(1.98 \%)$, familiarity with international technical standards (1.63\%), international knowledge structure $(1.63 \%)$, awareness of international innovation and competition (1.39\%), moral quality ( $1.10 \%)$, and social responsibility $(1.10 \%)$.

d) Total ranking of weight calculation

Based on the calculation results, the importance of the four secondary indicators was ranked according to their weights: multilingual language skills, communication and coordination skills, professional skills and diverse perspectives. This reflects the importance of mastering foreign language skills and using them as a fluent working language. As a joint Russian-Chinese program, the need for proficiency in the Russian language is even more emphasized. Secondly, according to the results of the calculations, the ability to communicate and coordinate is a necessary trait for a qualified international person, and comes second only to the ability to speak a foreign language. The development of modern education requires that international talents should be familiar with Chinese and foreign diversity, have good communication skills and the ability to communicate and cooperate internationally. Among the 15 three-level indicators, Russian language and English language ability each account for more than $20 \%$ of the weight, while other foreign language ability, cultural knowledge, and teamwork ability also account for nearly $10 \%$ of the weight. As shown in Table 7, the order of importance of the remaining three-level indicators is interpersonal competence, skill mastery, professional learning ability, organizational leadership, international cognition, international technical standards, international knowledge structure, international innovation and competitive awareness, moral quality and social responsibility [9]. 
Table 7 Total ranking weights

\begin{tabular}{|c|c|c|c|c|}
\hline $\begin{array}{l}\text { O level } 1 \\
\text { indicators }\end{array}$ & $\mathrm{C}$ level 2 indicators & $\mathrm{P}$ level 3 indicators & Weights & Ranking \\
\hline 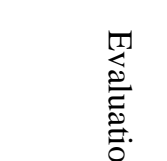 & $\begin{array}{l}\text { C1 Multilingual } \\
\text { language skills }\end{array}$ & $\begin{array}{c}\text { P1 Russian language skills } \\
\text { P2 English language skills } \\
\text { P3 Other foreign language skills }\end{array}$ & $\begin{array}{c}24.93 \% \\
24.93 \% \\
8.31 \%\end{array}$ & $\begin{array}{l}1 \\
1 \\
2\end{array}$ \\
\hline 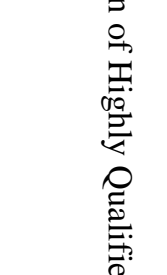 & $\begin{array}{c}\mathrm{C} 2 \text { Communication } \\
\text { and coordination skills }\end{array}$ & $\begin{array}{c}\text { P4 Interpersonal communication } \\
\text { skills } \\
\text { P5 Cultural knowledge base } \\
\text { P6 Teamwork ability } \\
\text { P7 Organizational leadership }\end{array}$ & $\begin{array}{l}6.41 \% \\
7.06 \% \\
7.06 \% \\
2.62 \%\end{array}$ & $\begin{array}{l}4 \\
3 \\
3 \\
7\end{array}$ \\
\hline 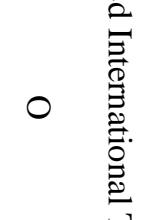 & C3 Professional skills & $\begin{array}{c}\text { P8 Professional learning ability } \\
\text { P9 Skill acquisition ability } \\
\text { P10 Moral quality } \\
\text { P11 Social responsibility }\end{array}$ & $\begin{array}{l}4.65 \% \\
5.20 \% \\
1.10 \% \\
1.10 \%\end{array}$ & $\begin{array}{c}6 \\
5 \\
11 \\
11\end{array}$ \\
\hline 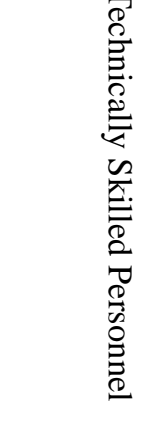 & C4 Diversified vision & $\begin{array}{c}\text { P12 International cognition, } \\
\text { thinking, vision } \\
\text { P13 Good knowledge of } \\
\text { international technical standards } \\
\text { P14 International knowledge } \\
\text { structure } \\
\text { P15 International innovative } \\
\text { competitive awareness }\end{array}$ & $\begin{array}{l}1.98 \% \\
1.63 \% \\
1.63 \% \\
1.39 \%\end{array}$ & 9 \\
\hline
\end{tabular}

Based on the weighting ranking of the talent cultivation quality evaluation system, it is obvious that international talents should be proficient in small working languages, have good human communication and teamwork skills, have solid knowledge base of professional skills, and have a certain understanding and knowledge of foreign diverse cultures. In order to further clarify the judgment of the results, the evaluation results of the three levels of indicators can be graded ---- $91 \leq$ excellent $\leq 100,76 \leq \operatorname{good} \leq 90,60 \leq$ qualified $\leq 75,0 \leq$ unqualified $\leq 59$, so as to realize the quantitative check of the indicator weights $[10,11]$.

\section{Application of the Evaluation System}

Using the AHP hierarchical analysis method as a tool, the evaluation system is constructed for 4 secondary indicators and 15 tertiary indicators, and the evaluation of the quality of internationalized talents training as an overall system, by decomposing the objectives by level, comparing and judging the importance of each element, then conducting a comprehensive analysis and calculating the weight of each indicator. Reflecting the importance played by the evaluation indexes on the quality of talent cultivation, it realizes the definition and judgment of the qualities possessed by internationalized technical skill talents, and initially establishes a complete talent quality evaluation system. This system can be used as a selective basis for schools to evaluate the quality of student training and for enterprises to judge the professional quality of employees.

a) University level 
Teaching institutions can adjust talent training programs and education plans based on the evaluation results, selectively highlighting a certain evaluation index to focus on training. While respecting the development of students' individuality and taking into account the generality of overall development, it is possible to implement hierarchical teaching. At the same time, as a teaching institution, it can implement diversified operations based on the evaluation results in the recommendation of targeted export of outstanding talents to employers. In addition, it is possible to establish a rewarding and merit-based selection mechanism for students' achievements and results, and personal growth based on the evaluation results.

\section{b) Company level}

As far as an employer is concerned, the evaluation results can be used as an important reference basis when the company recruits employees, and can objectively reflect to a certain extent the strengths and weaknesses, expertise and shortcomings of individual students in the process of growth, providing a strong judgment support for the objective selection of the company[12,13].

\section{V.Conclusion}

In the early 1970s, the U.S. Department of Defense has used AHP to establish multi-polar objectives to study the industrial power allocation problem. At present, AHP hierarchical analysis is widely studied in domestic and foreign academic circles, and has been deeply applied to regional economic planning, livestock development strategies, system analysis of industrial sector settings in France, Germany, the United Kingdom, Japan and other countries. As a new and effective decision-making method, AHP is always in our daily life, such as the choice of tourist attractions, college entrance examinations, and other problems facing comparative choices.

In this paper, the method is applied to the study of international talent quality evaluation system construction, which can realize the talent training evaluation of Sino-foreign cooperative education of projects and institutions regardless of the training mode, and can also evaluate the international talent training mode of teachers and students in exchange mode. However, this method is somewhat subjective in the selection of evaluation indexes, and the indexes should be adjusted according to the situation of universities or the characteristics of specific projects in the process of actual use, and the opinions of all parties should be more integrated when scoring the index values to avoid the final evaluation results reflecting personal preference, not objective enough, deviating from the overall goal of evaluation and appearing to be inconsistent with the actual education and training situation.

\section{Acknowledgement}

This paper is founded by:

1. 2020 Research on the teaching mode of Russian language in higher education institutions under the 'One Belt, One Road' strategy", general topics of the Thirteenth Five-Year Plan of Henan Provincial Education Science (2020YB0687),head: Cong QIAO;

2. 2019 Henan Province Higher Education Teaching Reform Research and Practice Key Project "Exploration and Practice of Cultivating Technical Skill Talents through Integration of Industry and Education under the International Perspective of 'One Belt, One Road'"(2019SJGLX650), head: Huayan XING;

3. 2018 Zhengzhou Railway Vocational Technology College Teaching and Research Key Project "Research on International Talent Training Quality Evaluation System"(2018JKY035),head: Huayan XING;

\section{References}


[1] Zhen, Li, SUN. Ideas of cultivating complex Russian language talents in the conditions of joint Russian-Chinese education. Journal of Chifeng College (Chinese version of philosophy and social science), vol:32, no:2, pp. 255-256, 2011.

[2] CHEN, Ni. AHP-based index system for evaluating the quality of cross-border talent training in universities. A Family of Words, no: 2, pp. 24-27, 2019.

[3] MIAOHui. The current situation and reform path of quality assessment of Sino-foreign cooperative education. Journal of Changchun College of Engineering (Social Science Edition), vol: 7, no: (3), pp. 98-101, 2016.

[4] E.N.ProshkinaAnalysis and prediction of students' performance on the basis of radial basis neural network/E.N. Proshkina, I.Y.-Text: direct//Technical Sciences: Traditions and Innovations: Young scientist, pp. 24-28, 2018.

[5] BIAN, Jiamin, JIANG Ling. The construction of internationalization evaluation index system of talent cultivation in higher vocational institutions. Talent Cultivation, no: 2, pp. 17-21, 2019.

[6] ZHAO Lingfei, LANG Lihua, MA Li. Exploration on the construction of internationalized talents evaluation system in higher education institutions--a comparative study based on AHP fuzzy comprehensive judgment method and principal component analysis. Journal of Yangzhou University (Higher Education Research Edition), no: 2, pp.10-18, 2019.

[7] LI Xinliang, HU Xiaohong. Research on internationalized talent training evaluation system. Human Resources, no:24, pp.131, 2016.

[8] I.P.Pastukhova Methodological support for designing control and evaluation tools for the discipline//Secondary vocational education.no: 10, pp. 3-6, 2011.

[9] WANG Yiquan, GUO Qiang. An AHP-based approach to evaluate the competitiveness of Sino-foreign cooperative schools. Modern Education Science, no: 6, pp.32-37, 2017.

[10] GE Xiaoli, WANG Yifan. Quality evaluation of internationalized talents training based on hierarchical analysis method - taking ACCA orientation class of Fuyang Normal University as an example. Journal of Chifeng College (Natural Science Edition), 2019(8):120-123.Gusev D.A.,Katyukhina O.A., Peculiarities of using the AHP method for multicriteria analysis of alternatives, Logistic systems in the global economy. no:5, pp.180-182, 2015.

[11] ANWei. Characteristics and inspiration of the assessment and evaluation system of vocational education in Britain. Jiangsu: Science and Technology Wealthy Guide, no: 35, 2011.

[12] Shupeng RUAN, Xiaoyong LIAO. A comprehensive quality evaluation method for college students based on AHP algorithm. Modern Business Industry, no: 14, pp.52-53, 2017.

[13] ZHANG Letian, LIU Dianhong. Research on the comprehensive quality evaluation system of higher vocational students based on AHP. Chinese Vocational and Technical Education,no: 26, pp. 39-42, 2015 . 